\title{
A framework to prioritise high-risk abandoned mine features for rehabilitation in Western Australia
}

\author{
I Mitchell Department of Mines, Industry Regulation and Safety, Australia \\ K Hryczyszyn Department of Mines, Industry Regulation and Safety, Australia \\ T Read Department of Mines, Industry Regulation and Safety, Australia
}

\begin{abstract}
Mining has occurred in Western Australia for more than 150 years, resulting in thousands of abandoned mine features across the state, such as shafts, costeans, large pit voids and waste rock landforms. The Abandoned Mines Program was made possible following the enactment of the Mining Rehabilitation Fund Act 2012 (WA) in July 2013. The Act provides a source of funding to address abandoned mine features in Western Australia. The Abandoned Mines Program was formally established following the release of the Western Australian Government's Abandoned Mines Policy in January 2016. A key component of the program is to develop a framework to actively identify and prioritise high-risk abandoned mine features so that associated safety and environmental risks can be addressed through suitable management practices and/or site rehabilitation while protecting the residual mineral value for potential future extraction. The health, safety or environmental risks and the potential historical, cultural, social, environmental, educational or economic value of these sites inform decisions about risk and future management.
\end{abstract}

Keywords: abandoned mines, risk assessment, prioritisation, risk management, rehabilitation

\section{Introduction}

Mineral exploration and extraction have been important activities economically in Western Australia since the late 1800s. More than a century of mining has resulted in a significant number of abandoned mine workings across the state that present risks to communities and the environment. During the early 1980s, the effects of mining on the environment became a key consideration in assessing and approving exploration and mining activities in Western Australia, and unconditional performance bonds were introduced to encourage tenement holders to rehabilitate sites prior to closure. In the event that rehabilitation obligations were not met, the state could utilise the bond to carry out rehabilitation and closure activities at the site. In recognition that the existing unconditional performance bonds did not cover the state's contingent liability to rehabilitate abandoned sites, the Mining Rehabilitation Fund Act 2012 (WA) (MRF Act) was enacted (Department of Mines and Petroleum [DMP] 2015; Gorey et al. 2014). The MRF Act requires tenement holders to pay an annual, non-refundable levy into a central fund, known as the Mining Rehabilitation Fund (MRF), which can be utilised by the state government to fund the rehabilitation of abandoned mine sites.

The Abandoned Mines Program, funded through the MRF, was formally established in 2015, and the Abandoned Mines Policy was released in 2016. The policy provides a framework for the assessment, prioritisation, management and rehabilitation of abandoned mine sites through the consideration of significant risks and potential historical, cultural, social and economic value associated with each site (DMP 2016a). This paper provides an overview of the risk assessment and prioritisation framework developed in accordance with the policy to identify and prioritise high-risk abandoned mine features for management and/or rehabilitation under the Abandoned Mines Program. 


\section{$2 \quad$ Mining securities in Western Australia}

Western Australia is the main minerals exporting region of Australia and produces a significant proportion of the world's minerals commodities (Department of Jobs, Tourism, Science and Innovation 2019).

In 2017-18, the mineral sector employed around 112,000 people, generated AUD 88 billion in sales value (DMP 2018a) and contributed AUD 4.9 billion in royalty revenue to the state government (Department of Treasury 2018). Along with the positive economic benefits associated with the mining industry, there is also the potential for negative social and environmental impacts. Land disturbance associated with active mining operations in Western Australia, legislated under the Mining Act 1978 (WA), totalled 164,756 ha in 2018 (DMP 2018b). Without effective management and rehabilitation, mining operations and mining-impacted land pose potential risks to human health and safety and to the environment. As such, the focus of mining regulation in Australia and around the world has been to establish regulatory processes to ensure that mining operations are conducted in a manner that limits the potential for adverse environmental and community impacts (Gorey et al. 2014). A component of this regulatory framework in many jurisdictions has been the imposition of mining securities on mining companies.

In Western Australia, mining securities were first imposed in the 1980s in the form of bank guaranteed unconditional performance bonds. The purpose of these bonds was to ensure that the state was not exposed to unacceptable costs should mine operators fail to meet the environmental rehabilitation requirements on their tenements (Gorey et al. 2014). A review of the bond system in 2011-12 found that the level of security provided by the unconditional performance bonds had not kept pace with the increasing costs and standards of rehabilitation (DMP 2015). In 1999, it was estimated that, on any particular site, the bonds held represented approximately $80 \%$ of the total cost of rehabilitation. By 2008, this had dropped to around $25 \%$ (DMP 2015).

In response to this increasing unfunded liability, the state reviewed alternatives to the bond system. The alternatives considered included the following options:

1. Retaining the use of unconditional performance bonds but increasing the bond amount to at least $100 \%$ of estimated rehabilitation cost.

2. Utilising insurance policies rather than bonds.

3. Establishing a new centralised fund that received compulsory, non-refundable contributions from operating mines (Gorey et al. 2014).

Following extensive stakeholder consultation, option three was selected, and the Western Australian parliament passed the MRF Act to establish a central fund.

The MRF Act made it a requirement that all holders of mining tenements granted under the Mining Act 1978 pay an annual, non-refundable levy into the MRF. The levy is based on the area of disturbed land associated with the tenement holder's operations (DMP 2015). Money in the principal fund can be used to rehabilitate abandoned mine sites where a tenement holder, who has contributed to the fund, fails to meet their rehabilitation obligations. Interest generated from the fund can be spent on administration of the MRF and the rehabilitation of historically abandoned mine sites that existed prior to the introduction of the MRF Act. The Abandoned Mines Program was established to deliver the management and/or rehabilitation of abandoned mine sites funded through the MRF.

\section{Abandoned Mines Program}

The West Australian Government's Abandoned Mines Program is guided by the Abandoned Mines Policy, released in 2016, which provides an overarching framework for the prioritisation, management and/or rehabilitation of abandoned mine sites in the state (DMP 2016a). The policy was developed with consideration to the Strategic Framework for Managing Abandoned Mines in the Minerals Industry (Ministerial Council on Mineral and Petroleum Resources [MCMPR] \& Minerals Council of Australia [MCA] 2010) and in consultation with stakeholders (DMP 2016b). The strategic framework describes five components for the successful implementation of an abandoned mines program that have been adopted and 
expanded upon as policy principles within the Abandoned Mines Policy (Unger et al. 2015; MCMPR \& MCA 2010; DMP 2016a):

1. Risk assessment and prioritisation.

2. Valuing abandoned mine sites.

3. Data collection and management.

4. Resourcing and partnership opportunities.

5. Information sharing and leading best practice.

The Abandoned Mine Policy requires that a risk-based approach, focused on community safety and environmental impacts, forms the basis for prioritising abandoned mines sites for management and/or rehabilitation. A risk assessment and prioritisation framework has been developed under the Abandoned Mines Program in accordance with the objectives and principles outlined in the policy to enable a consistent approach to be applied in determining priority sites. An inventory of abandoned mines collated by the Geological Survey of Western Australia (GSWA) in the early 2000s was used in the development of the risk assessment and prioritisation framework.

\subsection{Abandoned mines inventory}

Following a fatal accident at an abandoned mine site near Cue in central Western Australia in 1997, the Western Australian Government initiated funding for a program to develop an inventory of abandoned mine features in the state (Ormsby et al. 2003). In 1999, the GSWA began development of the abandoned mines inventory as the first step to identifying the abandoned mine sites in the state and determining the safety and environmental hazards that they pose. Fieldwork to collate the data was conducted between 1999 and 2011. Field efforts were prioritised to include those sites within $10 \mathrm{~km}$ of populated towns of 200 people or more and/or within $1 \mathrm{~km}$ of major roads (Ormsby et al. 2003). Consideration was also given to sites that had records of past accidents and stakeholder feedback including information received from local governments (Ormsby et al. 2003). The result was the collation of more than 192,000 records that now comprise the abandoned mines inventory, accessible to the public via the Department of Mines, Industry Regulation and Safety's (DMIRS) Mines and Mineral Deposits database (MINEDEX) and GeoView.WA, an interactive GIS-based mapping system. The collection of data ceased after 2011 and no material updates to the inventory have occurred since.

The abandoned mines inventory comprises records of individual mining-related features - such as a single shaft, open pit void or landform - rather than abandoned mine sites that may comprise multiple features. Figure 1 shows the distribution of abandoned mine features recorded on the inventory.

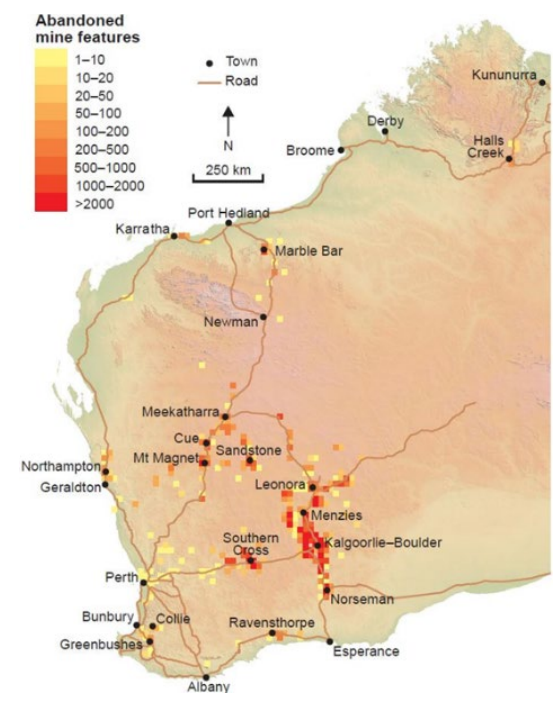

Figure 1 Distribution of abandoned mine features recorded in Western Australia 
Table 1 provides a breakdown of the type of features recorded and the percentage representation within the inventory. As shown in Table 1, shallow workings make up more than half of the features recorded. Shallow workings are defined as a pit, cavity, hole or other uncovered cutting produced by excavation that is less than $2 \mathrm{~m}$ in depth. The table also demonstrates that features most often associated with significant environmental risks, such as tailings dumps (tailings storage facilities) and waste dumps (waste rock landforms), make up less than $2 \%$ of the features recorded.

The abandoned mines inventory, along with new information provided by departments and the community, is used as the basis of the risk assessment and prioritisation framework described in the following sections.

Table 1 Abandoned mines inventory breakdown

\begin{tabular}{|c|c|c|c|c|}
\hline Feature group & Feature type & Number & $\%$ & Description \\
\hline Shallow workings & Shallow working & 99,093 & 51.5 & Excavation less than $2 \mathrm{~m}$ deep \\
\hline \multirow[t]{4}{*}{ Underground } & Shaft & 21,548 & 11.2 & Greater than 2 m deep \\
\hline & Open stope & 2,294 & 1.2 & Vertical or inclined underground excavation \\
\hline & Subsidence & 1,655 & 0.9 & Surface subsidence due to internal collapse \\
\hline & Other & 722 & 0.3 & Adit, drillhole, multiple shafts, well \\
\hline Rehabilitated & Rehabilitated & 18,398 & 9.5 & Restored to a previous condition \\
\hline \multirow[t]{2}{*}{ Open cut } & Costean/trench & 15,333 & 8.0 & Narrow shallow ditch for exploration \\
\hline & Pit/quarry & 1,129 & 0.6 & $\begin{array}{l}\text { Mine, quarry, excavation worked by open } \\
\text { cut }\end{array}$ \\
\hline \multirow[t]{4}{*}{ Dump } & Rubbish dump & 6,039 & 3.1 & $\begin{array}{l}\text { General rubbish, scrap metal and other } \\
\text { material }\end{array}$ \\
\hline & Waste dump & 2,506 & 1.3 & Mine waste or spoil material \\
\hline & Tailings dump & 1,004 & 0.5 & Processing/treatment waste material \\
\hline & Other dump & 1,418 & 0.8 & Ash, leach pad, ramp, rock and soil \\
\hline Collapsed shafts & Collapsed shaft & 9,945 & 5.2 & $\begin{array}{l}\text { Less than } 2 \mathrm{~m} \text { deep, with evidence of } \\
\text { greater original depth }\end{array}$ \\
\hline Infrastructure & Infrastructure & 7,524 & 3.9 & Buildings, dam/sumps, machinery and other \\
\hline $\begin{array}{l}\text { Under } \\
\text { infrastructure }\end{array}$ & $\begin{array}{l}\text { Under } \\
\text { infrastructure }\end{array}$ & 3,915 & 2.0 & $\begin{array}{l}\text { Beneath or removed by more recent } \\
\text { development }\end{array}$ \\
\hline Total & & 192,523 & 100 & \\
\hline
\end{tabular}

\section{$4 \quad$ Risk assessment and prioritisation framework}

The framework for the assessment and prioritisation of abandoned mine features was developed in accordance with the Abandoned Mines Policy (DMP 2016a), which outlines a three-stage process for identifying and prioritising high-risk features-that is, preliminary screening, risk assessment, and prioritisation assessment. The risk assessment and the prioritisation process are presented in Figure 2 with further detail provided below. 


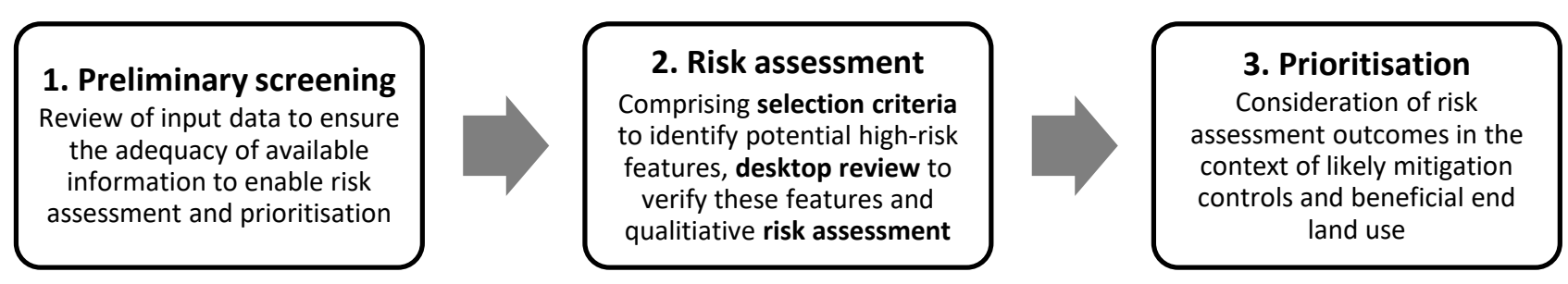

Figure 2 Risk assessment and prioritisation framework

\subsection{Preliminary screening}

The abandoned mines inventory dataset developed by the GSWA contains information relating to feature type, location, dimensions and condition as well as an assessment of safety risks associated with each feature by considering identified hazards and risk modifiers. The risk assessment model applied to the inventory was developed for the former Department of Industry and Resources to facilitate the consistent assessment of physical safety hazards posed by abandoned mine features (GHD Pty Ltd 2005). While the model considered chemical hazards, such as asphyxiant atmosphere and combustible material, there was insufficient information in the inventory dataset to adequately assess these hazards. In addition, the model does not consider environmental risks due to the need for a more detailed site-specific assessment of environmental values (GHD Pty Ltd 2005). However, some information recorded within the inventory can be used to assist in identifying features that may present risks to the environment.

A comprehensive analysis of the abandoned mines inventory dataset was undertaken to evaluate the adequacy of available information for the assessment of risk and prioritisation of high-risk abandoned mine features. Key considerations included the age of records, scope of the risk assessment, attribute completeness, and metadata comprehensibility. The evaluation identified attribute data that was complete and appropriate to support the risk assessment and prioritisation of abandoned mine features for the purpose of rehabilitation and/or management under the Abandoned Mines Program, in accordance with the Abandoned Mines Policy (DMP 2016a).

\subsection{Risk assessment}

The risk assessment process identifies abandoned mine features that present the highest safety and/or environmental risk for consideration in the prioritisation assessment. Given the large number of records within the inventory, a three-step risk assessment process was developed comprising feature selection, desktop review and qualitative risk assessment, as described in the following sections.

\subsubsection{Selection criteria}

Multiple selection criteria were developed to minimise the likelihood of high-risk features being omitted due to limitations inherent in each individual criterion. The highest-ranked features selected based on each criterion were merged and saved in an output geodatabase. The four selection criteria applied were:

- Risk score: Selects features from the inventory with the highest 'total risk score' as assessed by the GSWA based on the risk assessment model developed by GHD Pty Ltd (2005). The total risk score is calculated using hazard identifiers (e.g. steep drop, falling material, standing water) and risk modifiers that alter the likelihood or consequence of an event that might be caused by a hazard (e.g. location, accessibility, visibility, depth, barriers, signage). It is noted that the total risk score considers physical safety hazards only. Example scoring for particular feature types are provided in Table 2.

- Risk scenario: Selects features from the inventory that have attributes that present a potential health, safety or environmental hazard and are within a defined distance to a sensitive community or environmental receptor. This selection criteria comprise six risk scenarios that may occur if a 
feature is accessed: falls from height, entrapment, crush by falling material, open water/swimmer distress, air pollution, water pollution and drinking water pollution. Features selected were ranked based on total risk score or area as relevant to each risk scenario.

- Contaminated sites: Selects features from the inventory that intersect high-risk contaminated sites, as determined in consultation with the Department of Water and Environmental Regulation, and are considered likely to contribute to contamination (e.g. leach pads, tailings storage facilities and waste rock landforms).

- Stakeholder input: Selects features reported by the community or other stakeholders including departmental input that warrant further investigation.

Applying these criteria resulted in the selection of 256 abandoned mine features.

Table 2 Example hazards, risk modifiers and total risk scores for feature types

\begin{tabular}{|c|c|c|c|c|c|c|}
\hline Feature type & Shaft & $\begin{array}{l}\text { Open } \\
\text { stope }\end{array}$ & $\begin{array}{l}\text { Costean/ } \\
\text { trench }\end{array}$ & $\begin{array}{l}\text { Pit/ } \\
\text { quarry }\end{array}$ & Leach pad & $\begin{array}{l}\text { Infrastruct } \\
\text { ure }\end{array}$ \\
\hline \multicolumn{7}{|l|}{ Hazards } \\
\hline H1: Steep/vertical drop & 4 & 4 & 4 & 4 & 2 & 2 \\
\hline H2: Falling material & & & & & & 1 \\
\hline H3: No means of egress & 3 & 3 & & & & \\
\hline H4: Standing water & 2 & & & 2 & & \\
\hline Hazard score & 9 & 7 & 4 & 6 & 2 & 3 \\
\hline \multicolumn{7}{|l|}{ Risk modifiers } \\
\hline RM1: Location & 3 & 3 & 2 & 3 & 3 & 1 \\
\hline RM2: Accessibility & 2 & 3 & 2 & 2 & 3 & 2 \\
\hline RM3: Visibility & 2 & 2 & 0 & 0 & 0 & 0 \\
\hline RM4: Depth/height & 5 & 1 & 1 & 3 & 1 & 1 \\
\hline RM5: Barrier to entry & 3 & 3 & 1 & 2 & 1 & 1 \\
\hline RM6: Signage & 1 & 1 & 1 & 1 & 1 & 1 \\
\hline RM7: Unsafe ladder/ramp & 0 & 0 & 0 & 0 & 0 & 0 \\
\hline $\begin{array}{l}\text { RM8: Loose or unstable } \\
\text { ground }\end{array}$ & 2 & 2 & 1 & 0 & 0 & 1 \\
\hline Risk modifier score & 18 & 15 & 8 & 11 & 9 & 7 \\
\hline Total risk score & 162 & 105 & 32 & 44 & 18 & 21 \\
\hline Potential risk category & Significant & Significant & Insignificant & Marginal & Insignificant & Insignificant \\
\hline
\end{tabular}

Source: Adapted from GHD Pty Ltd (2005)

\subsubsection{Desktop review}

A detailed desktop review was undertaken to verify that each of the identified features had the potential to represent the risk for which it was selected. The assessment primarily comprised a review of aerial imagery considering a number of factors, as described in Table 3. Criteria for deprioritising features (Table 3) were applied during the desktop review unless additional factors indicated that a feature should remain a priority for further assessment (e.g. proximity to sensitive receptors such as waterways). Other factors considered 
during the desktop review include evidence of significant erosion and potential contamination. Current mining tenure rehabilitation obligations and management responsibility were also reviewed where aerial imagery indicated that new operations may exist in association with the feature. Information recorded against each feature informed the qualitative risk assessment as described in Section 4.2.3.

Table 3 Review of aerial imagery

\begin{tabular}{|c|c|c|c|}
\hline Factor & Evidence from aerial imagery ${ }^{1}$ & Relevant risk scenario & $\begin{array}{l}\text { Criteria for } \\
\text { deprioritising }\end{array}$ \\
\hline Bare earth & Significant bare earth & Air pollution, water pollution & $>50 \%$ ground cove \\
\hline $\begin{array}{l}\text { Distance to } \\
\text { dwelling }\end{array}$ & $\begin{array}{l}\text { Distance to nearest dwelling } \\
\text { associated with a town }\end{array}$ & $\begin{array}{l}\text { Fall, crush, entrapment, } \\
\text { swimmer distress, air pollution }\end{array}$ & $\begin{array}{l}>10 \mathrm{~km} \text { from town } \\
\text { dwellings }\end{array}$ \\
\hline Population & $\begin{array}{l}\text { Density of dwellings reviewed } \\
\text { against population data }\end{array}$ & $\begin{array}{l}\text { Fall, crush, entrapment, } \\
\text { swimmer distress, air pollution }\end{array}$ & $\begin{array}{l}\text { Nearest town } \\
\text { population }<500 \\
\text { people }\end{array}$ \\
\hline $\begin{array}{l}\text { Standing } \\
\text { water }\end{array}$ & Standing water in the feature & Swimmer distress & $\begin{array}{l}\text { No standing water } \\
\text { visible }\end{array}$ \\
\hline
\end{tabular}

${ }^{1}$ Western Australia Land Information Authority (Landgate) (2017)

${ }^{2}$ Australian Bureau of Statistics (2016)

Features were deprioritised where evidence indicated that the identified risk was not present. This primarily occurred where the hazard was not evident on aerial imagery, the feature was distant from sensitive community or environmental receptors, or where the feature was located on land now under a new land use (e.g. active mining operations). The list was further refined to 161 features following the desktop review.

\subsubsection{Qualitative risk assessment}

A qualitative risk assessment was undertaken of the identified features with consideration to the department's risk assessment framework. The desktop review was used to inform the risk assessment by allowing adjustments to the consequence or likelihood ratings based on site-specific information, such as changes to likelihood based on distance to dwellings and observations of population density. The qualitative risk assessment resulted in a refined list of 96 features that represented the highest safety and/or environmental risk for further consideration in the prioritisation assessment. These features could largely be categorised into two groups:

- Fall from height risks associated with underground shafts and open pits close to towns or urban centres.

- Contaminated sites risks to the environment and/or community associated with an abandoned mine feature or features.

\subsection{Prioritisation}

A prioritisation assessment of high-risk features identified through the risk assessment process was undertaken considering likely mitigation controls, associated costs and time frames. The characterisation of mitigation controls resulted in two groups of high-risk features - those with low-cost and short time frame mitigation controls, and those with high-cost long time frame mitigation controls. Features in the low-cost short time frame group comprise shafts, adits and open stopes that could be effectively closed through capping or minor earthworks to backfill. These were prioritised using the total risk score as assessed by the GSWA. Features in the high-cost long time frame group generally comprise large tailings storage facilities and open cut pits that would require significant investigations, planning and remediation works. Further investigations are required to assign priority to these features, including detailed desktop assessments, site inspections and engagement with key stakeholders. The prioritisation assessment methodology will be 
further refined considering other factors including alternate land use, potential future mining, heritage conservation and long-term benefits (DMP 2016a).

\section{Continuous improvement}

With the framework to prioritise high-risk abandoned mine features now in place, the process of working through the abandoned mines inventory and addressing the priority features is underway. In conjunction with the analysis of each feature, the framework will continue to be assessed for improvements in the prioritisation process. The inventory is the main platform underlying the Abandoned Mines Program risk assessment and prioritisation framework, and it has not been actively managed since its establishment in 2011-that is, no new data has been added to the inventory or the existing data updated. For example, features previously identified as abandoned may now not exist through the development of a new mine. Similarly, and as discussed in Section 3.1, fieldwork to collate abandoned mine features was prioritised to those sites within $10 \mathrm{~km}$ of populated towns of 200 people or more and/or within $1 \mathrm{~km}$ of major roads. There are, therefore, potentially many other abandoned mine features that have not yet been recorded.

Stakeholder engagement will continue to be critical to ensuring the ongoing success of the Abandoned Mines Program in implementing the prioritisation framework. An essential component of this engagement will be in the support of maintaining the inventory. In this instance, stakeholders include-but are not limited tomembers of the community, industry, other government agencies and other divisions within DMIRS, which manages the Abandoned Mines Program. While stakeholders are encouraged to report a potential abandoned mine feature through the form located on the DMIRS web page, ongoing efforts will be required to ensure critical stakeholders are fully cognisant and engaged with the process to ensure the right features are being prioritised in the ongoing framework analysis.

\section{Conclusion}

Western Australia, like other mining jurisdictions around the world, has a legacy of many abandoned mine features that present risks to communities and the environment. This paper has provided an overview of the risk assessment and prioritisation framework developed to identify and prioritise high-risk abandoned mine features for management and/or rehabilitation under the Abandoned Mines Program.

The framework has been developed to assess the level of risk associated with each feature in a robust and repeatable way. The process has been defined, so it can be consistently applied as more records are added to the inventory. This will then ensure new features added to the inventory are assigned the relevant ranking and prioritised for action appropriately.

\section{Acknowledgement}

The authors acknowledge Joe Chandler who made a significant contribution to the development of this framework during his time with DMIRS. The authors also acknowledge members of the Mining Rehabilitation Advisory Panel who provided valuable feedback on the draft risk assessment and prioritisation framework.

\section{References}

Australian Bureau of Statistics 2016, Urban Centre and Locality (UCL) Ed 2016, Australian Bureau of Statistics, Canberra.

Department of Mines and Petroleum 2015, The Mining Rehabilitation Fund - The First Two Years, Department of Mines and Petroleum, Perth.

Department of Mines and Petroleum 2016a, Abandoned Mines Policy, Department of Mines and Petroleum, Perth.

Department of Mines and Petroleum 2016b, Abandoned Mines Policy for Stakeholder Comment: Response to Submissions October 2015, Department of Mines and Petroleum, Perth.

Department of Mines and Petroleum 2018a, Western Australian Mineral and Petroleum Statistics Digest 2017-18, Department of Mines and Petroleum, Perth.

Department of Mines and Petroleum 2018b, Mining Rehabilitation Fund Yearly Report 2017-18, Department of Mines and Petroleum, Perth. 
Department of Jobs, Tourism, Science and Innovation 2019, Western Australia Economic Profile February 2019, Department of Jobs, Tourism, Science and Innovation, Perth.

Department of Treasury 2018, Overview of State Taxes and Royalties 2017-18, Department of Treasury, Perth.

GHD Pty Ltd 2005, WA Abandoned Mines Risk Assessment Model - Risk Assessment Guidance Manual, GHD Pty Ltd, Perth.

Gorey, P, Morrison-Saunders, A, Doepel, D, Mtegha, H \& McHenry, MP 2014, 'Dealing with mining legacies: from bonds to a central mining rehabilitation fund in Western Australia', in IM Weiersbye, AB Fourie, M Tibbett \& K Mercer (eds), Proceedings of the 9th International Conference on Mine Closures, The University of the Witwatersrand, Johannesburg.

Ministerial Council on Mineral and Petroleum Resources \& Mineral Council of Australia 2010, Strategic Framework for Managing Abandoned Mines in the Minerals Industry, Ministerial Council on Mineral and Petroleum Resources \& Mineral Council of Australia, Canberra.

Ormsby, WR, Howard, HM \& Eaton, NW 2003, Inventory of Abandoned Mine Sites: Progress 1999-2002, Geological Survey of Western Australia, Department of Industry and Resources, Perth.

Unger, CJ, Lechner, AM, Kenway, J, Glenn, V \& Walton, A 2015, 'A jurisdictional maturity model for risk management, accountability and continual improvement of abandoned mine remediation programs', Resources Policy, vol. 43, pp. 1-10.

Western Australia Land Information Authority (Landgate) 2017, WA Now Mosaic, Western Australia Land Information Authority, Midland. 
